\title{
Spontaneous uterine rupture in the 35th week of gestation after laparoscopic adenomyomectomy
}

This article was published in the following Dove Press journal:

International Medical Case Reports Journal

18 December 2015

Number of times this article has been viewed

\author{
Yukari Nagao ${ }^{1,2}$ \\ Kazuhiro Osato ${ }^{2,3}$ \\ Michiko Kubo \\ Takuya Kawamura ${ }^{2}$ \\ Tomoaki Ikeda ${ }^{3}$ \\ Takaharu Yamawaki ${ }^{2}$ \\ 'Department of Obstetrics and \\ Gynecology, Japanese Red Cross \\ Nagoya Daiichi Hospital, Aichi, \\ ${ }^{2}$ Department of Obstetrics and \\ Gynecology, Japanese Red Cross \\ Ise Hospital, Mie, ${ }^{3}$ Department of \\ Obstetrics and Gynecology, School of \\ Medicine, Mie University, Mie, Japan
}

\begin{abstract}
Uterine rupture rarely occurs during pregnancy, but it is a critical situation if so. It is already known that a history of uterine surgeries, such as cesarean section or myomectomy, is a risk factor for uterine rupture. Currently, the laparoscopic adenomyomectomy is a widely performed procedure, but associated risks have not been defined. We observed a case of spontaneous uterine rupture in a patient during the 35th week of gestation, after a laparoscopic adenomyomectomy. A 42-year-old, gravida 2, para 0 woman became pregnant after a laparoscopic adenomyomectomy and her pregnancy was conventional. At a scheduled date in the 35th week of gestation, after combined spinal epidural anesthesia and frequent uterine contractions, a weak pain suddenly ensued. After 13 minutes of uterine contractions, vaginal bleeding was evident. A cesarean section was performed, and the uterine rupture was found in the scar. After a laparoscopic adenomyomectomy, a pregnant uterus can easily rupture by rather weak and short uterine contractions, and is characterized by vaginal bleeding. When uterine bleeding is observed in pregnant women that have a history of adenomyomectomy, one should consider uterine rupture.
\end{abstract}

Keywords: uterine rupture, pregnancy, laparoscopic adenomyomectomy, uterine contraction, vaginal bleeding

\section{Introduction}

Uterine rupture rarely occurs during pregnancy, but it is a critical obstetric complication associated with maternal and fetal mortality and morbidity. ${ }^{1}$ It is known that the rate of uterine rupture increases in patients with a history of uterine surgery, such as cesarean section or myomectomy. Laparoscopic adenomyomectomies are widely performed to treat infertility or palliate symptoms of menstruation. It is however, not yet known what kinds of complications this procedure can cause in pregnant women. Here we report a case of spontaneous uterine rupture in the 35 th week of gestation after a laparoscopic adenomyomectomy.

\section{Case report}

A 42-year-old, gravida 2, para 0 woman was referred to our hospital at the 11 th week of gestation. Before she got pregnant, she had had sterility treatment, but it hadn't been successful. She subsequently received a laparoscopic adenomyomectomy in another hospital 14 months before referral. The findings in the operation were as follows: The lesion of adenomyosis existed at the posterior wall of the uterus and the lesion and rectum adhered to each other firmly. A vertical incision was made in the middle of the posterior wall of the uterus, and the adenomyosis lesion was enucleated as much as
Correspondence: Yukari Nagao

Department of Obstetrics and

Gynecology, Japanese Red Cross Nagoya

Daiichi Hospital, 3-35 Michishita-cho,

Nakamura-ku, Nagoya,

Aichi 453-85II, Japan

Tel +8 I 52 48I 5 III

Fax +81524827733

Email yu_yu_yu_yukari_0516@yahoo.

co.jp
International Medical Case Reports Journal 2016:9 I-4

Dovepres:

http://dx.doi.org/10.21 477/IMCRJ.594363 (c) (1) (2) ๑ 2016 Nagaa et al. This work is published by Dove Medical Press Limited, and licensed under Creative Commons Attribution - Non Commercial (unported, v3.0)

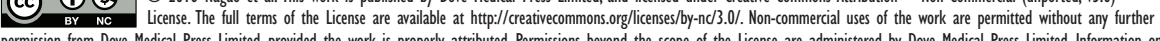
issions beyond the scope of the License are administered by Dove Medical Press Limited. Information on how to request permisision may be found at. http://www.dovepress.com/permissions.php 


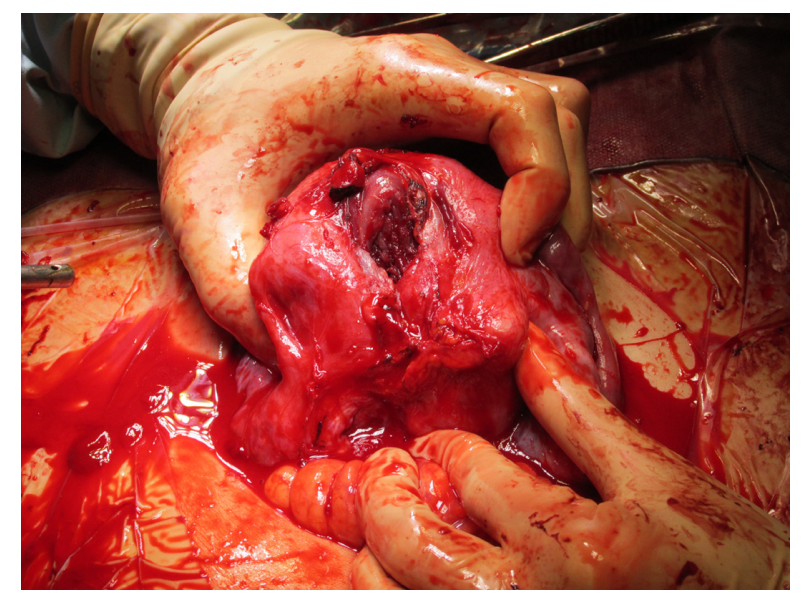

Figure I Uterine rupture with a $1.5 \mathrm{~cm}$ hole.

Note: One area did not have a muscle layer and was covered with only uterine serosa adjacent to the ruptured area.

possible (50 $\mathrm{g}$ in total). Finally, the uterine wall was repaired with a three-layer suture. One year after the operation, she conceived spontaneously.

The patient's singleton pregnancy was uneventful and she was admitted at the 30th week of gestation for the purpose of bed rest. This was done because past reports suggest that uterine rupture after laparoscopic adenomyomectomy typically occurs around the 30th week of gestation. The patient's hospital stay was incident-free, and a cesarean section was due to be performed at the 34 th week of gestation to achieve optimal trade-off between fetal lung maturation and fetal prematurity. However, the patient's cesarean section was moved to the 35 th week of gestation due to her strong request. On the scheduled date, no notable events occurred until the patient went into the operating room. The patient had undergone combined spinal epidural anesthesia, and was experiencing frequent uterine contractions when a weak pain suddenly occurred. After 13 minutes of uterine contractions, vaginal bleeding was observed while sterilizing the vagina. Cesarean section was performed immediately and a female neonate, weighing 2,283 g, was delivered 31 minutes after uterine contractions had begun. The neonate's Apgar scores were 7 and 8 at 1 and 5 minutes, respectively. Umbilical arterial gas analysis indicated no acidosis $(\mathrm{pH}$ 7.267, base excess -3.4).

The rectum and omentum adhered to the posterior uterine wall, where there was a scar from the previous adenomyomectomy. Bleeding was found in the adhered tissue and therefore we peeled off those adhesions. A 1.5 $\mathrm{cm}$ hole was found in the uterus (Figure 1). One area did not have a muscle layer and was covered with only uterine serosa adjacent to the ruptured area. This was repaired with a three-layer suture and total sutured length was 7-8 cm. The patient's postoperative process proceeded without complications and the patient was discharged at a postoperative date of 12 days. Informed consent was obtained from the patient orally, in order to retain the anonymity of the patient. No ethics approval was required for this study.

\section{Discussion}

Two important clinical issues were identified: 1) after a laparoscopic adenomyomectomy, a pregnant uterus might rupture easily by rather weak and short uterine contractions; 2) uterine contractions followed by uterine bleeding might be useful for the diagnosis of uterine rupture.

First, after laparoscopic adenomyomectomy, a pregnant uterus might rupture easily by rather weak and short uterine contractions. A recent review by Morimatsu et al showed that the rate of uterine rupture after adenomyomectomy during pregnancy is $6.0 \%{ }^{2}$ in contrast to the entire rate of uterine rupture during pregnancy, which is $0.035 \% .^{3}$ This is much higher than the rate of complications after cesarean section

Table I Characteristics in five cases of uterine rupture during pregnancy after adenomyomectomy

\begin{tabular}{|c|c|c|c|c|c|c|c|c|c|}
\hline $\begin{array}{l}\text { Author } \\
\text { (year) }\end{array}$ & $\begin{array}{l}\text { Age } \\
\text { (years) }\end{array}$ & $\begin{array}{l}\text { Operative } \\
\text { method }\end{array}$ & $\begin{array}{l}\text { Contraception } \\
\text { period } \\
\text { (months) }\end{array}$ & $\begin{array}{l}\text { Gravida }(\mathbf{G}), \\
\operatorname{para}(\mathbf{P})\end{array}$ & $\begin{array}{l}\text { GA } \\
\text { (weeks) }\end{array}$ & $\begin{array}{l}\text { Uterine } \\
\text { contraction or } \\
\text { abdominal pain }\end{array}$ & $\begin{array}{l}\text { Uterine } \\
\text { bleeding }\end{array}$ & Outcome & $\begin{array}{l}\text { Delivery } \\
\text { method }\end{array}$ \\
\hline $\begin{array}{l}\text { Suginami } \\
(2001)^{10}\end{array}$ & NA & Laparoscopic & $\mathrm{NA}(>3)$ & NA & 32 & NA & NA & Live birth & $\begin{array}{l}\text { Emergency } \\
\text { cesarean section }\end{array}$ \\
\hline $\begin{array}{l}\text { Wada et al } \\
(2006)^{\prime \prime}\end{array}$ & 33 & Laparoscopic & 12 & GOPO & 30 & + & - & Live birth & $\begin{array}{l}\text { Emergency } \\
\text { cesarean section }\end{array}$ \\
\hline $\begin{array}{l}\text { Morimatsu } \\
\text { et al }(2007)^{2}\end{array}$ & 35 & Laparoscopic & I & GIPI & 28 & + & - & Live birth & $\begin{array}{l}\text { Emergency } \\
\text { cesarean section }\end{array}$ \\
\hline $\begin{array}{l}\text { Onishi et al } \\
(201 \mathrm{I})^{8}\end{array}$ & 40 & Laparotomic & $\begin{array}{l}\text { NA } \\
\text { (about } 2 \text { years) }\end{array}$ & G3PI & 31 & + & - & Live birth & $\begin{array}{l}\text { Emergency } \\
\text { cesarean section }\end{array}$ \\
\hline $\begin{array}{l}\text { Our case } \\
(20 \mid 4)\end{array}$ & 42 & Laparoscopic & II & G2P0 & 35 & + & + & Live birth & $\begin{array}{l}\text { Elective } \\
\text { cesarean section }\end{array}$ \\
\hline
\end{tabular}

Notes: +, present; -, absent.

Abbreviations: GA, gestational age; NA, not available. 
Table 2 Pregnancy outcome in patients with prior history of adenomyomectomy

\begin{tabular}{llllll}
\hline Author (year) & Number of cases & Abortion or still birth & Live birth & Uterine rupture & Operative method \\
\hline Suginami $(2001)^{10}$ & 17 & $\mathrm{I}$ & 16 & $\mathrm{I}$ & Laparoscopic \\
Matsuura et al $(2004)^{12}$ & $\mathrm{II}$ & 4 & 7 & 0 & Laparotomic \\
Fujishita $(2006)^{13}$ & 5 & 3 & 2 & 0 & Laparotomic \\
Wada et al $(2006)^{11}$ & 18 & $\mathrm{I}$ & 17 & 2 (abortion I, live birth I) & Laparoscopic \\
Takeuchi et al $(2006)^{14}$ & $\mathrm{I}$ & 0 & $\mathrm{I}$ & 0 & Laparoscopic \\
Morimatsu et al $(2007)^{2}$ & $\mathrm{I}$ & 0 & $\mathrm{I}$ & $\mathrm{I}$ & Laparoscopic \\
Ota et al $(2009)^{9}$ & 4 & 0 & 4 & 0 & Laparoscopic \\
Onishi et al $(2011)^{8}$ & $\mathrm{I}$ & 0 & $\mathrm{I}$ & $\mathrm{I}$ & Laparotomic \\
Osada et al $(2011)^{15}$ & 16 & 14 & 0 & Laparotomic \\
Saremi et al $(2014)^{16}$ & $2 \mathrm{I}$ & 2 & 16 & 0 & Laparoscopic \\
Our case $(2014)$ & $\mathrm{I}$ & 5 & $\mathrm{I}$ & $\mathrm{I}$ & Laparoscopic \\
\hline
\end{tabular}

$(0.27 \%-0.7 \%)^{4,5}$ or myomectomy $(2.45 \%){ }^{6,7}$ We determined some reasons why uterine rupture frequently occurs in pregnant women with prior laparoscopic adenomyomectomies. The boundary between the normal uterine muscle layer and the lesion is unclear. A lesion of adenomyosis tends to remain around the edges of excisions and the area to be sutured, which might lead to weak connections between sutured edges. If a lesion of adenomyosis is enucleated widely to eliminate the lesion, the uterus will be small and irregular in shape, which leads to a diminished capacity to expand. ${ }^{8}$ With a laparoscopic adenomyomectomy, it is particularly difficult to delineate the border of the lesion because of a lacking sense of touch and deep sensation. ${ }^{9}$

Only five publications have presented cases of uterine rupture during pregnancy in patients with prior histories of adenomyomectomy (laparoscopic 4, laparotomic 1) (Table 1), ${ }^{2,8,10,11}$ According to 96 reported cases (Table 2), ${ }^{2,8-16}$ the rate of uterine rupture during pregnancy was $6.25 \%$; this is similar to the review reported by Morimatsu et al. ${ }^{2}$ It would appear that the frequency of uterine rupture after laparoscopic adenomyomectomy is higher than that of laparotomic adenomyomectomy (Tables 1 and 2), but there is no cohort study to compare these so far.

Uterine rupture or dehiscence during pregnancy tends to occur more frequently after laparoscopic myomectomy than after laparotomic myomectomy. Specifically, the frequency of uterine dehiscence is $1.85-4.94 \%$ in laparoscopic ${ }^{6,7}$ and $0 \%$ in laparotomic (this finding is extremely limited because it depends on only 69 cases from two reports). ${ }^{6,7}$ We guess that uterine rupture or dehiscence is similarly more common in laparoscopic than in laparotomic adenomyomectomy cases.

Second, uterine contractions followed by uterine bleeding might be useful for the diagnosis of uterine rupture. Uterine rupture does not have any typical symptoms and is often asymptomatic. ${ }^{17,18}$ Classical symptoms and signs are abdominal pain, external bleeding, vital signs indicating shock, disappearance of labor pain, and signs of fetal distress etc. In this case, the patient experienced both abdominal pain and external bleeding.

\section{Conclusion}

A pregnant uterus after laparoscopic adenomyomectomy might rupture easily by rather weak and short uterine contractions. Furthermore, uterine contractions followed by uterine bleeding might be useful for the diagnosis of uterine rupture. When uterine contractions are followed by uterine bleeding in pregnant women that have had a prior adenomyomectomy, this must be considered a potential sign of uterine rupture. If physicians are planning to perform surgery for treating sterility and infertility, they should carefully choose the modality of surgery and get more detailed informed consent from patients with adenomyosis. Further reports should be accumulated to develop more reliable and safe operative techniques, and to establish guidelines for pregnancy after adenomyomectomy in women of reproductive age.

\section{Disclosure}

The authors report no conflicts of interest in this work.

\section{References}

1. Yazawa H, Endo S, Hayashi S, Suzuki S, Ito A, Fujimori K. Spontaneous uterine rupture in the 33rd week of IVF pregnancy after laparoscopically assisted enucleation of uterine adenomatoid tumor. J Obstet Gynaecol Res. 2011;37(5):452-457.

2. Morimatsu Y, Matsubara S, Okuchi A, et al. Shikyūsenkinshō kakushutsujutsu go no ninshin - Shikyū haretsu no literature review to sanka kanri ni tsuite - [Pregnancy after adenomyomectomy - literature review of uterine rupture and obstetrical management -]. Sanka to fujinka [Japanese Journal of Obstetrics and Gynaecology] 2007;74(9):1047-1053. Japanese.

3. Ofir K, Sheiner E, Levy A, Katz M, Mazor M. Uterine rupture: risk factors and pregnancy outcome. Am J Obstet Gynecol. 2003;189(4): 1042-1046.

4. Guise JM, McDonagh MS, Osterweil P, Nygren P, Chan BK, Helfand M. Systematic review of the incidence and consequences of uterine rupture in women with previous caesarean section. BMJ. 2004;329(7456):19-25. 
5. Landon MB, Hauth JC, Leveno KJ, et al; for National Institute of Child Health and Human Development Maternal-Fetal Medicine Units Network. Maternal and perinatal outcomes associated with a trial of labor after prior cesarean delivery. $N$ Engl J Med. 2004;351(25): 2581-2589.

6. Kim MS, Uhm YK, Kim JY, Jee BC, Kim YB. Obstetric outcomes after uterine myomectomy: Laparoscopic versus laparotomic approach. Obstet Gynecol Sci. 2013;56(6):375-381.

7. Tian YC, Long TF, Dai YM. Pregnancy outcomes following different surgical approaches of myomectomy. J Obstet Gynaecol Res. 2015; 41(3):350-357.

8. Onishi K, Hiromura K, Miyazaki K, et al. Shikyūsenkinshō setsujojutsu go ninshin ni okeru zenchi kannyū taiban, shikyū haretsu no ichi rei [A case of uterine rupture in a patient with placenta previa and accreta following adenomyomectomy]. Nihon shūsanki shinseiji igakkai zasshi. [J Jpn Soc Perin Neon Med.] 2011;47(4):947-950. Japanese.

9. Ota Y, Hada T, Deura I, et al. Fukukūkyō ka shikyūsenkinshō setsujojutsu - byōsō no keijō ni chūmoku shita jutsushiki no tsukaiwake [Laparoscopic adenomyomectomy - the use of a method focusing attention on the shape of the lesion]. Sanka to fujinka [Japanese Journal of Obstetrics and Gynaecology] 2009;76(12):1547-1553. Japanese.

10. Suginami H. Shikyūsenkinshō shujutsu deno ninyōnō onzon [Fertility preservation following an adenomyosis operation]. Sanka to fujinka [Japanese Journal of Obstetrics and Gynaecology] 2001; 68(8): 1017-1022. Japanese.

11. Wada S, Kudo M, Minakami H. Spontaneous uterine rupture of a twin pregnancy after a laparoscopic adenomyomectomy: a case report. J Minim Invasive Gynecol. 2006;13(2):166-168.
12. Matsuura K, Honda R, Okamura H. Kaifuku ni yoru shikyūsenkinshō kakushutsujutsu - kakyuteki byōsō shukushōjutsu kara mita chiryō seiseki - [Laparoscopic adenomyomectomy - the result of treatment following an operation that limits the size/ number of lesions]. Nihon Seishokugeka gakkai zasshi [Japanese Reproductive Surgery Society Magazine] 2004;17(1):9-13. Japanese.

13. Fujishita A. Shikyūsenkinshō ni taisuru sikyū onzon shujutsu [Conservative surgery for adenomyosis]. Sanfujinka chiryō [Treatment of Obstetrics and Gynaecology] 2006;92(3):294-298. Japanese.

14. Takeuchi H, Kitade M, Kikuchi I, et al. Laparoscopic adenomyomectomy and hysteroplasty: a novel method. J Minim Invasive Gynecol. 2006;13(2):150-154

15. Osada H, Silber S, Kakinuma T, Nagaishi M, Kato K, Kato O. Surgical procedure to conserve the uterus for future pregnancy in patients suffering from massive adenomyosis. Reprod Biomed Online. 2011; 22(1):94-99.

16. Saremi A, Bahrami H, Salehian P, Hakak N, Pooladi A. Treatment of adenomyomectomy in women with severe uterine adenomyosis using a novel technique. Reprod Biomed Online. 2014;28(6):753-760.

17. Guiliano M, Closset E, Therby D, LeGoueff F, Deruelle P, Subtil D. Signs, symptoms and complications of complete and partial uterine ruptures during pregnancy and delivery. Eur J Obstet Gynecol Reprod Biol. 2014;179:130-134.

18. Hashiguchi M. Shikyū haretsu [Uterine rupture]. Sanka to fujinka [Japanese Journal of Obstetrics and Gynaecology] 2012;79(5):573-581. Japanese.
International Medical Case Reports Journal

\section{Publish your work in this journal}

The International Medical Case Reports Journal is an international, peer-reviewed open-access journal publishing original case reports from all medical specialties. Previously unpublished medical posters are also accepted relating to any area of clinical or preclinical science. Submissions should not normally exceed 2,000 words or

\section{Dovepress}

4 published pages including figures, diagrams and references. The manuscript management system is completely online and includes a very quick and fair peer-review system, which is all easy to use. Visit http://www.dovepress.com/testimonials.php to read real quotes from published authors. 